\title{
Suhtautuminen perhepoliittisiin toimenpiteisiin
}

\author{
HELI EKMAN
}

Tässä kirjoituksessa selvitetään väestön suhtautumista perhepoliittisiin toimenpiteisiin, sitä missä määrin perhepoliittisten toimenpiteiden nähdään auttavan perhettä suorittamaan sille kuuluvat tehtävät sekä kuinka tarkoituksenmukaisina näitä toimenpiteitä pidetään. Samoin pyritään tutkimaan joidenkin kirjallisuudessa esitettyjen perhepoliittisten toimenpiteiden tarpeellisuutta ja tarkoituksenmukaisuutta. Perhepolitiikan toimintalohkot jaetaan kolmeen osaan: perhekustannusten yleistasaukseen pyrkiviin toimenpiteisiin, joista huomio kiinnitetään vain lapsilisiin ja äidinpalkkioon, asumiskustannuksia tasaaviin toimenpiteisiin, joista otetaan huomioon vain lapsiperheiden asumistuki ja perhepalveluun, missä kiinnitetään huomio vain perheen kiinteyttä lisääviin toimenpiteisiin.

Kysymykset, joihin pyritään saamaan vastaus, ovat seuraavat: Mitkä ovat pääasialliset syyt väestön kasvun heikkenemiseen? Voidaanko perhekustannusten yleistasaamisen avulla edistää väestön kasvua? Kuinka suhtaudutaan täyskompensaatioon? Onko lapsiperheiden asumistuki nykyisellään kyllin suuri rohkaisemaan perheitä muuttamaan tarpeeksi tilaviin asuntoihin? Voitaisiinko äidinpalkkion avulla rohkaista äitejä jäämään pois ansiotyöstä? Pidetäänkö perheneuvontaa tarpeellisena?

Tutkimus ${ }^{1}$, johon tämä selvitys perustuu, on suoritettu Tampereen Yliopistossa lukuvuonna 1965-66. Tutkimusai-

1 Lyhennelmä sosiaalipolitiikan pro gradu-tutkielmasta, Tampereen Yliopisto v. 1966 . neisto on kerätty haastattelemalla 127 tamperelaista, lapsilisää saavaa äitiä. Sosiaaliryhmiin jako on suoritettu käyttämällä hyväksi Helsingin kaupungin Tilastotoimiston suosittelemaa jaotusta, jossa väestö on jaettu neljään sosiaaliryhmään (Helsingin kaupungin Tilastotoimisto 1954; 37-44.) Tässä tutkimuksessa on aineiston pienuuden vuoksi yhdistetty kaksi ylintä ja kaksi alinta sosiaaliryhmää. Alempaan sosiaaliryhmään kuului 67 haastateltua äitiä ja ylempään sosiaaliryhmään 60 äitiä.

\section{Suhtautuminen perhekustannusten yleistasaustoimenpiteisiin}

Väestölliset tekijät ovat olleet perhekustannusten tasauksen lähtökohtana. On ajateltu, että syy lapsirajoitukseen on halu kohottaa elintasoa ja asumistasoa hankkimalla yhden tai korkeintaan kaksi lasta. On kuitenkin vaikea arvoida, missä määrin perhekustannusten tasaamisella voidaan edistää väestön kasvua. Joidenkin henkilöiden mielestä voi olla jopa moraalisesti väärin, että yhteiskunta yrittää perhekustannusten tasaamisen avulla edistää väestön kasvua.

Eräänä syntyvyyteen vaikuttavana tekijänä voidaan pitää kulloinkin yhteiskunnassa vallitsevia, perheen kokoa koskevia ihanteita. Syntyvyyden säännöstelyn tultua yhä yleisemmäksi teolliselle yhteiskunnalle ominainen rationalisuus on ulottunut perhe-elämään asti. Tällöin perheen koko pyritään sovittamaan taloudellisten tekijöiden asettamien vaatimusten mukaiseksi. Viime vuosikymmeninä on Amerikassa ja Ruotsissa voitu havaita 
syntyvyyden lisääntymistä varsinkin ylemmissä sosiaaliryhmissä. Tor Hartmanin ja Pentti Puumalaisen tutkimuksen tulokset antavat tukea hypoteesille, että nykyajan pitkälle teollistuneen yhteiskunnan ihanteet suosivat suurempaa lapsilukua kuin teollistumisen alkuvaiheessa olevan yhteiskunnan ihanteet (Hartman ja Puumalainen 1960; 61). Tämä antaisi aihetta olettaa, että pitkälle teollistuneessa yhteiskunnassa perheet ovat halukkaita hankkimaan itselleen runsaasti lapsia, mikäli perheen varat sen sallivat. Alemmassa sosiaaliryhmässä olevien perheiden voidaan olettaa painottavan enemmän kuin ylempään sosiaaliryhmään kuuluvien perheiden taloudellisia tekijöitä lapsirajoituksen syinä. Alempaan sosiaaliryhmään kuuluvien perheiden voi- daan myös olettaa olevan halukkaampia kuin ylempään sosiaaliryhmään kuuluvien perheiden hankkimaan enemmän lapsia, mikäli yhteiskunta nykyistä suuremmassa määrin korvaisi lapsista aiheutuvat kustannukset. Samoin voidaan alempaan sosiaaliryhmään kuuluvien perheiden olettaa olevan halukkaampia kuin ylempään sosiaaliryhmään kuuluvien perheiden ottamaan vastaan yhteiskunnan tukitoimenpiteitä (Kuusi 1961; 10).

Tässä tutkimuksessa saaduista tuloksista voidaan todeta, että vastaajat painottivat lapsirajoituksen syinä ensisijaisesti taloudellisia tekijöitä. Tiedusteltaessa vastaajilta, miksi heidän mielestään perheet nykyään ovat pienempiä kuin aikaisemmin, jakautuivat vastaukset seuraavasti:

\begin{tabular}{|c|c|c|c|c|c|c|}
\hline & \multirow{2}{*}{\multicolumn{4}{|c|}{ Sosiaaliryhmä }} & \multirow{2}{*}{\multicolumn{2}{|c|}{ yhteensä }} \\
\hline & & I & \multicolumn{2}{|c|}{ II } & & \\
\hline & luku & $\%$ & luku & $\%$ & luku & $\%$ \\
\hline Liian pienet asunnot $\ldots .$. & 2 & 3,3 & 1 & 1,4 & 3 & 2,5 \\
\hline Aitien ansiotyössä käyminen ..... & 13 & 21,5 & 18 & 27,0 & 31 & 24,5 \\
\hline Lapsista aiheutuvat kustannukset .. & 8 & 13,5 & 13 & 19,5 & 21 & 16,5 \\
\hline Vastuu lasten tulevaisuudesta on & & & & & & \\
\hline nykyään suurempi $\ldots \ldots \ldots \ldots \ldots \ldots$ & 32 & 53,0 & 30 & 44,7 & 62 & 48,6 \\
\hline Jokin muu syy $\ldots \ldots \ldots \ldots \ldots \ldots \ldots \ldots \ldots \ldots \ldots$ & 5 & 8,2 & 5 & 7,4 & 10 & 7,9 \\
\hline & 60 & 100 & 67 & 100 & 127 & 100 \\
\hline
\end{tabular}

Tutkittaessa perhepoliittisten toimenpiteiden vaikutusta vastaajien halukkuuteen hankkia itselleen enemmän lapsia voidaan todeta, että varsinkin ylempään sosiaaliryhmään kuuluvien joukossa on perin vähän niitä, jotka olisivat halukkaita hankkimaan itselleen enemmän lapsia, mikäli yhteiskunta nykyistä suuremmassa määrin korvaisi lapsista aiheutuvat kustannukset. Perhekustannusten tasaamistoimenpiteiden vaikutus perheiden halukkuuteen lisätä lapsilukuaan ilmenee seuraavasta asetelmasta:

\begin{tabular}{|c|c|c|c|c|c|c|}
\hline & \multicolumn{4}{|c|}{ Sosiaaliryhmä } & \multirow{2}{*}{\multicolumn{2}{|c|}{ yhteensä }} \\
\hline & luku & I $\%$ & luku & $\%$ & & \\
\hline \multirow{4}{*}{$\begin{array}{l}\text { Hankkisivat } \\
\text { Eivät hankkisi } \\
\text { Ei osaa sanoa }\end{array}$} & 5 & 8,0 & 17 & 26,1 & 22 & 17,5 \\
\hline & 45 & 75,5 & 36 & 55,5 & 81 & 65,0 \\
\hline & 10 & 16,5 & 12 & 18,4 & 22 & 17,5 \\
\hline & 60 & 100 & 65 & 100 & 125 & 100 \\
\hline
\end{tabular}

Koska ei katsottu korrektiksi esittää tätä kysymystä aviottomille äideille, joita aineistossa oli kaksi, on vastaajien kokonaislukumäärä kahta tapausta vähäisempi kuin muutoin.
Saadut tulokset tukevat olettamusta, että alempaan sosiaaliryhmään kuuluvat olisivat halukkaampia kuin ylempään sosiaaliryhmään kuuluvat hankkimaan itselleen enemmän lapsia, mikäli yhteis- 
kunta nykyistä suuremmassa määrin korvaisi lapsista aiheutuvat kustannukset $(\mathrm{t}=2,73 \mathrm{p}<1)$.

Edellä oleva asetelma antaa ehkä kuitenkin liian epäedullisen kuvan perhekustannusten tasaustoimenpiteiden vaikutuksesta perheiden halukkuuteen lisätä lapsilukuaan. Voidaan olettaa, että varsinkin ylempään sosiaaliryhmään kuuluvien joukossa on runsaasti sellaisia, jotka suhtautuvat kielteisesti yhteiskunnallisiin tukitoimenpiteisiin ja tästä syystä kieltä- vät itse olevansa halukkaita hankkimaan enemmän lapsia, vaikka yhteiskunta nykyistä suuremmassa määrin korvaisikin lapsista aiheutuvat kustannukset. Kuitenkin he uskovat, että perhekustannuksia tasaavilla toimenpiteillä voisi olla väestön kasvua lisäävä vaikutus. Tiedusteltaessa vastaajilta, luulevatko he, että perheet olisivat nykyistä suurempia, mikäli yhteiskunta nykyistä suuremmassa määrin korvaisi lapsista aiheutuvat kustannukset, muodostui vastausjakautuma seuraavaksi:

\begin{tabular}{|c|c|c|c|c|c|c|}
\hline & \multicolumn{6}{|c|}{ Sosiaaliryhmä } \\
\hline & \multicolumn{2}{|c|}{ I } & \multicolumn{2}{|c|}{ II } & \multicolumn{2}{|c|}{ yhteensä } \\
\hline & luku & $\%$ & luku & $\%$ & luku & $\%$ \\
\hline \multirow{4}{*}{$\begin{array}{l}\text { Olisivat suurempia } \ldots \ldots \ldots \ldots \ldots \ldots \\
\text { Eivät olisi suurempia } \ldots \ldots \ldots \ldots \ldots \ldots \\
\text { Ei osaa sanoa } \ldots \ldots \ldots \ldots \ldots \ldots \ldots\end{array}$} & 22 & 37,8 & 24 & 35,8 & 46 & 36,2 \\
\hline & 33 & 54,3 & 33 & 49,4 & 66 & 52,0 \\
\hline & 5 & 8,5 & 10 & 14,3 & 15 & 11,8 \\
\hline & 60 & 100 & 67 & 100 & 127 & 100 \\
\hline
\end{tabular}

Kuitenkaan ei lapsilisien korottamisella nähty olevan väestön kasvua edistävää vaikutusta, sillä vain $18 \%$ vastaajista uskoi, että monessa perheessä olisi nykyistä enemmän lapsia, mikäli lapsilisät olisivat suurempia kuin nykyään.

Monet vastaajat olivat kuitenkin sitä mieltä, että olisi tarpeellista ja tarkoituksenmukaista, että yhteiskunta nykyistä suuremmassa määrin korvaisi lapsista aiheutuvat kustannukset. Kuitenkaan vastaajat eivät yleensä olleet sitä mieltä, että yhteiskunnan tulisi kokonaan korvata lapsista aiheutuvat kustannukset. Alempaan sosiaaliryhmään kuuluvien joukossa oli kuitenkin huomattavasti enemmän kuin ylempään sosiaaliryhmään kuuluvien joukossa niitä, jotka puolsivat täyskompensaatiota $(p<5)$. Suhtautuminen täyskompensaatioon ilmenee seuraavista asetelmista:

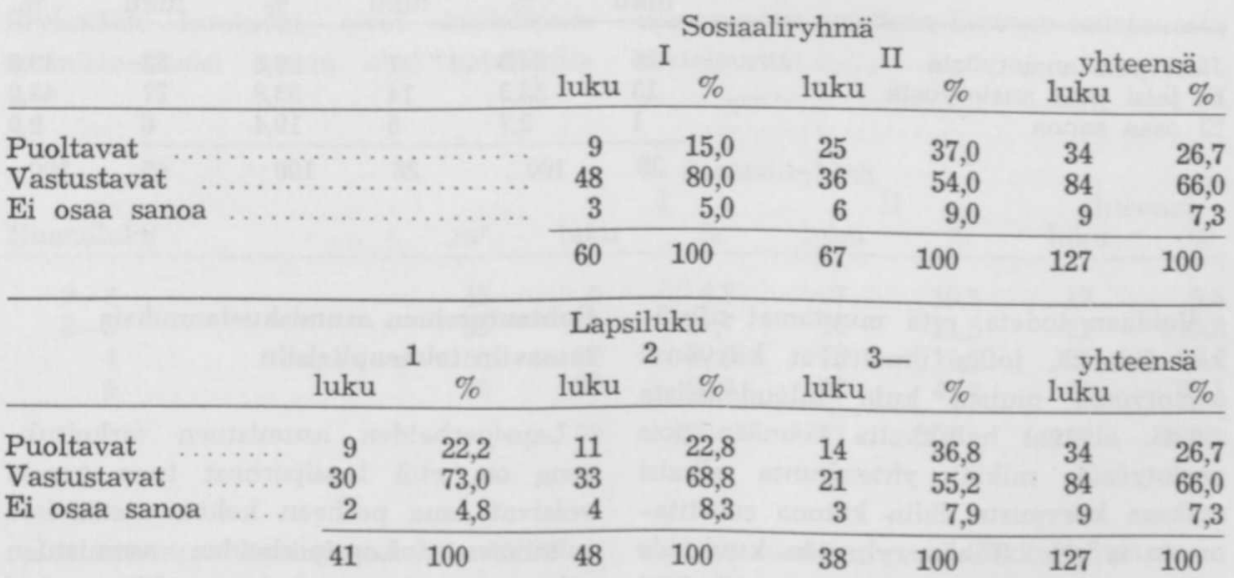

Jälkimmäinen asetelma osoittaa, että mitä suurempi perheen lapsiluku on, sitä useammat vastaajat puoltavat täyskompensaatiota. 
Tutkimuksessa pyrittiin myös selvittämään äidinpalkkion vaikutusta äitien halukkuuteen jäädä pois ansiotyöstä. Tutkimusaineistoon kuuluneista äideistä kävi ansiotyössä 65 äitiä. Heistä kuului ylempään sosiaaliryhmään 28 äitiä ja alempaan sosiaaliryhmään 37 äitiä.

Aidinpalkkion vaikutus äidin halukkuuteen jäädä pois ansiotyöstä riippunee suuresti niistä tekijöistä, joiden takia äidit käyvät ansiotyössä. Suurin osa $(55 \%)$ alempaan sosiaaliryhmään kuuluvista äideistä kävi ansiotyössä siksi, että heidän miestensä tulot olivat liian pienet. Ylempään sosiaaliryhmään kuuluvilla äideillä taas oli pääasiallisena syynä työssä käyntiin joko se, että he viihtyivät työssään $(25 \%)$ tai olivat työskennelleet monta vuotta hankkiakseen nykyisen ammattitaitonsa $(21,4 \%)$.

Tarkasteltaessa sosiaaliryhmittäin äitien halukkuutta jäädä pois ansiotyöstä, mikäli yhteiskunta alkaisi maksaa korvausta äidin kotona suorittamasta työstä, muodostuu vastausjakautuma seuraavaksi:

\begin{tabular}{|c|c|c|c|c|c|c|}
\hline & \multirow{2}{*}{\multicolumn{4}{|c|}{ Sosiaaliryhmä }} & \multirow{2}{*}{\multicolumn{2}{|c|}{ yhteensä }} \\
\hline & I & & \multicolumn{2}{|c|}{ II } & & \\
\hline & luku & $\%$ & luku & $\%$ & luku & $\%$ \\
\hline Jäisi pois ansiotyöstä & 12 & 42,8 & 20 & 55,5 & 32 & 49,0 \\
\hline $\mathrm{Ei}$ jäisi pois ansiotyöstä & 13 & 46,3 & 14 & 38,3 & 27 & 42,0 \\
\hline $\mathrm{Ei}$ osaa sanoa $\ldots \ldots \ldots \ldots$ & 3 & 10,0 & 3 & 8,0 & 6 & 9,0 \\
\hline & 28 & 100 & 37 & 100 & 65 & 100 \\
\hline
\end{tabular}

Jos tarkastellaan äitien halukkuutta jäädä pois ansiotyöstä sen mukaan, minkä äidit ilmoittivat työssä käymisensä syyksi, voidaan todeta, että taloudellisista syistä työssä käyvät äidit ovat halukkaampia kuin muista syistä työssä käyvät äidit jäämään pois ansiotyöstä, mikäli yhteiskunta alkaisi maksaa korvausta äidin kotona suorittamasta työstä:

\begin{tabular}{|c|c|c|c|c|c|c|}
\hline & \multicolumn{4}{|c|}{$\begin{array}{cc}\text { Työssä käynnin syy } \\
\text { taloudellinen }\end{array}$} & \multicolumn{2}{|c|}{ yhteensä } \\
\hline & luku & $\%$ & luku & $\%$ & luku & $\%$ \\
\hline \multirow{4}{*}{$\begin{array}{l}\text { Jäisi pois ansiotyöstä } \\
\text { Ei jäisi pois ansiotyöstä } \ldots \ldots \ldots \ldots \ldots \ldots \\
\text { Ei osaa sanoa } \ldots \ldots \ldots \ldots \ldots \ldots \ldots \ldots \ldots\end{array}$} & 25 & 64,0 & 7 & 26,8 & 32 & 49,0 \\
\hline & 13 & 33,3 & 14 & 53,8 & 27 & 42,0 \\
\hline & 1 & 2,7 & 5 & 19,4 & 6 & 9,0 \\
\hline & 39 & 100 & 26 & 100 & 65 & 100 \\
\hline
\end{tabular}

Voidaan todeta, että muutamat niistäkin äideistä, jotka ilmoittivat käyvänsä ansiotyössä muista kuin taloudellisista syistä, olisivat halukkaita jäämään pois ansiotyöstä, mikäli yhteiskunta alkaisi maksaa korvausta äidin kotona suorittamasta työstä. Tähän ryhmään kuulunee sellaisia äitejä, jotka käyvät ansiotyössä ensisijaisesti hankkiakseen rahaa omaan käyttöönsä itse työn silti suurestikaan heitä kiinnostamatta.

\section{Suhtautuminen asumiskustannuksia tasaaviin toimenpiteisiin}

Lapsiperheiden asumistuen tarkoituksena on, että lapsiperheet tuen turvin voisivat asua perheen kokoa vastaavissa asunnoissa. Lapsiperheiden asumistuen periaatteena on, että lapsiperheet voisivat asua kyllin tilavissa asunnoissa tarvitsematta silti uhrata enempää kuin $20 \%$ tuloistaan asumiskustannuksiin. Ei 
kuitenkaan ole varmaa, että kaikki perheet olisivat halukkaita maksamaan 20 $\%$ :a tuloistaan asumiskustannuksina. Varsinkin huonossa sosioekonomisessa asemassa olevien on havaittu olevan haluttomia lisäämään asumiskustannuksiaan ja arvostavan asumisväljyyttä vähemmän kuin paremmassa sosioekonomisessa asemassa olevien (Sukselainen 1950,47).

Lapsiperheiden asumistuen vaikutusta perheen halukkuuteen muuttaa kyllin tilaviin asuntoihin pyrittiin tutkimaan laskemalla Tampereen keskivuokrien perusteella erikokoisten asuntojen vuokrat siinä tapauksessa, että perhe asunnossa asuessaan saisi asumistukea. Haastateltavilta tiedusteltiin, minkä kokoista asuntoa he pitäisivät sopivimpana heidän perheelleen, jos vuokrat olisivat edellä kuvattuja.

Tiedusteltaessa vastaajilta, kuinka suurta asuntoa he pitivät tarpeellisena ja tarkoituksenmukaisena heidän perheelleen, jos heidän ei tarvitsisi ottaa asumiskustannuksia huomioon, voitiin todeta, että ylempään sosiaaliryhmään kuuluvat vastaajat pitivät tarpeellisena jonkin verran suurempaa asuntoa kuin alempaan sosiaaliryhmään kuuluvat vastaajat. Asunnon kokoa koskevat arvostukset ilmenevät seuraavasta asetelmasta (tässä kuten muissakin asetelmissa, joissa ilmenee asunnon koko, on keittiö luettu huoneeksi):

\begin{tabular}{|c|c|c|c|c|c|c|c|}
\hline \multirow[b]{2}{*}{ Huoneluku } & & \multicolumn{4}{|c|}{ Sosiaaliryhmä } & \multicolumn{2}{|c|}{ yhteensä } \\
\hline & & luku & $\%$ & luku & $\%$ & $\begin{array}{l}\text { yht } \\
\text { luku }\end{array}$ & asä \\
\hline $1-2$ & & 3 & 5,0 & - & - & 3 & 2.3 \\
\hline 3 & & 8 & 13,2 & 20 & 31,2 & 28 & 22,0 \\
\hline 4 & & 21 & 35,0 & 30 & 44,7 & 51 & 40,3 \\
\hline 5 & & 19 & 31,5 & 16 & 24,0 & 35 & 27,6 \\
\hline $6-$ & & 9 & 15,0 & 1 & 1,3 & 10 & 7,9 \\
\hline & & 60 & 100 & 67 & 100 & 127 & 100 \\
\hline
\end{tabular}

Voidaan myös todeta, että perheet lapsiperheiden asumistuen turvin olisivat halukkaita muuttamaan huomattavasti tilavampiin asuntoihin kuin missä he todellisuudessa asuivat. Alempaan sosiaaliryhmään kuuluvat eivät kuitenkaan asumistuenkaan turvin olisi halukkaita uhraamaan asumismenoihinsa niin suurta osaa tuloistaan, että voisivat asua yhtä tilavasti kuin ylempään sosiaaliryhmään kuuluvat. Lapsiperheiden asumistuen vaikutus perheiden halukkuuteen muuttaa tilavampaan asuntoon ilmenee seuraavasta asetelmasta:

\begin{tabular}{|c|c|c|c|c|c|c|c|}
\hline \multirow[b]{2}{*}{ Huoneluku } & \multicolumn{7}{|c|}{ Sosiaaliryhmä } \\
\hline & $\mathrm{m}^{2}$ & luku & $\%$ & luku & $\%$ & $\begin{array}{r}\text { yh } \\
\text { luku }\end{array}$ & sã \\
\hline $2-3$ & 45 & 5 & 8,3 & 7 & 10,5 & 12 & 9,5 \\
\hline $2-3$ & 55 & 7 & 11,7 & 14 & 21,5 & 21 & 16,2 \\
\hline 4 & 65 & 12 & 20,0 & 13 & 19,5 & 25 & 19,0 \\
\hline 5 & 75 & 38 & 60,0 & 33 & 47,6 & 69 & 54,5 \\
\hline & & 62 & 100 & 67 & 100 & 127 & 100 \\
\hline
\end{tabular}

Jos verrataan saatuja tuloksia UIOF:n kansainvälisen asumiskomission kokouksessa 1957 hyväksyttyihin perheasuntojen vähimmäisnormeihin (kts. Kuusi 1961, 148) voidaan todeta, että monet perheet olisivat tuen turvin halukkaita asumaan niin tilavissa asunnoissa kuin vähimmäisnormit suosittelevat. Useat vastaajat eivät kuitenkaan pitäneet tarkoituksenmukaisena asua niin tilavissa asunnoissa 
kuin vähimmäisnormit edellyttävät, vaikka he voisivat jättää asumiskustannukset huomioon ottamatta.

\section{Suhtautuminen perhepalveluun}

Voidaan sanoa, että kaikki ne toimenpiteet, jotka kohottavat perheen kulutustasoa ja antavat perheelle mahdollisuuden kohottaa asumistasoaan, jotta perheen jäsenten fyysinen ja psyykinen kuntoisuus säilyisi hyvänä, auttavat perhettä suorittamaan tehtävänsä. Eräänä perheen tärkeänä tehtävänä on turvallisuuden antaminen. Jotta perhe voisi suoda turvaa, tulisi sen olla melko kiinteä. Avioerojen lisääntyminen on aiheuttanut sen, että perheen mahdollisuudet turvan antajana ovat vähentyneet. Perhepoliittisin keinoin, estämällä epäonnistumaan tuomitut avioliitot ja pyrkimällä lujittamaan jo olemassa olevia avioliittoja, voidaan lisätä perheen kiinteyttä (Karlsson 1959, 88-91). Epäonnistuvien avioliittojen estämiseksi ehdottaa Karlsson, että nuorille olisi tarpeeksi ajoissa annettava perheneuvontaa, jotta heidän odotuksensa avioliittoa kohtaan muodostuisivat realistisiksi ja olemassa olevien avioliittojen lujittamiseksi olisi tehostettava avioliittoneuvontaa. Kaikki vaikeuksissa olevat eivät kuitenkaan itse tunne tarvitsevansa neuvontaa eivätkä hae kosketusta neuvoa antaviin elimiin.

Tässä tutkimuksessa saaduista tuloksista voidaan todeta, että vastaajat eivät yleensä pitäneet perheneuvonnan lisäämistä tarpeellisena. Kaikki vastaajat eivät edes tienneet, minkälaisissa tapauksissa voisi kääntyä perheasiain neuvottelukeskuksen tai avioliittoneuvolan puoleen.
Vain seitsemän vastaajaa oli joskus käynyt avioliittoneuvolassa tai perheasiain neuvottelukeskuksessa ja vain kolme vastaajaa niistä, jotka eivät koskaan olleet näissä toimistoissa käyneet, olivat joskus aikoneet mennä perheasiainneuvottelukeskukseen tai avioliittoneuvolaan. Nuorten parien avustamisessa vastaajat pitivät asuntojen hankkimista ja kodinperustamislainoja huomattavasti tärkeämpänä kuin avioliittoneuvontaa.

Perheneuvonta lienee vielä niin uutta, että perheet eivät ole tottuneet käyttämään näiden toimistojen palveluksia hyväkseen.

\section{Kirjallisuus}

Hartman, T-Puumalainen, P. Aviollisen hedelmällisyyden vaihteluista Suomessa. Väestöntutkimuksen vuosikirja VI. Vammala 1960.

Harva, $U$. Ihminen hyvinvointivaltiossa. Rauma 1964.

Helsingin kaupungin tilastotoimisto. Tilastollisia kuukausitietoja Helsingistä 3/1954.

Karlsson, G. Barnfamiljernas ekonomi och äktenskapets stabilitet, sisältyy teokseen Vad händer med familjen. Stockholm 1959.

Kuusi, P. 60-luvun sosiaalipolitiikka. Porvoo 1961.

Laki lapsiperheiden asumistuesta.

Statens Offentliga Utredningar. Ökat stöd till barnfamiljer. Stockholm 1964: 36 .

Sukselainen, V. J. Perhekustannusten tasaaminen. Väestöpoliittisen tutkimuslaitoksen julkaisuja. Sarja A: 4 Helsinki 1950. 